\title{
Role of T.V Media Contents in Reshaping Perception of Educated Youth A Case Study of Gujrat Regarding T.V News and Current Affair
}

\author{
Arshad Ali (PhD) ${ }^{1,}$ Aneela Karamat (M Phil Fellow) ${ }^{2,}$ \\ Syed Ali Hassan (M Phil Fellow) ${ }^{3}$

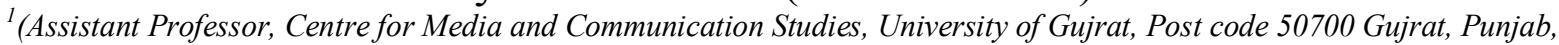 \\ Pakistan) \\ 2 (Centre for Media and Communication Studies, University of Gujrat, Post code 50700 Gujrat, Punjab, Pakistan) \\ 3 (Centre for Media and Communication Studies, University of Gujrat, Post code 50700 Gujrat, Punjab, Pakistan)
}

\begin{abstract}
Today media is more corresponding, tricky and dependent on the dominant elites. This has become increasing concern considering the extreme media effects can have over the perceptions of its viewers. The electronic media (TV) of Pakistan and its one way information effects on educated youth of Gujrat. In current scenario TV media have been unsuccessful to provide the public interest. Therefore, survey sample size 100 took from Gujrat educated youth findings of paper represents that mostly educated youth rely on TV media information and discuses it with peer and family group. It also clearly the educated youth of Gujrat still has doubts over the sources and reliability of information being provided to them. However, electronic media outlets provide the information that set the agenda of educated youth.
\end{abstract}

Keywords: Educated youth, electronic media, T.V, one side information, News content, perception

\section{Introduction}

Today world mass media consider as a most powerful tool to educate and change the perception and behavior. Many media gurus assume that TV media may influence the perceptions of the educated Youth hugely. Among young, adults and worldwide television has become the dominant medium (UNICEF). Media effects are changes in knowledge, attitude, or behavior that result from exposure to the mass media (Davenport, Larose, \& Straubhaar, 2006). Media generate cultural and political products that have different ideas from many other goods, and also media are national property, not simple consumer goods. In modern society, the media are essential to processes of thought, education, and social integration. The educated Youth of any country is considered as the "Nation Builders" and they can play a significant role in the development of the country not only economically but also by morally and practically. In fact educated youth group can play a major role in changing the democracy (Ali, 2011).

Today's youth are broadly rely on media for information, whether it is news about war or televised presidential debates or many other social or national issues. However, a huge amount of research has established that the use and content of news media have larger effects on public perception (Davison, 1983, Gunther, 1998). TV Media is a key source of information; modern educated youth depend on it for information. TV Media does not only inform the general public, but also, in varying ways, informally educate them. As compare to other media, television provides a relatively limited set of options for a virtually unlimited range of interests and the public (.Gerbner et. al, 1986). Therefore, in a democratic society, media, rather than simply supplying consumer goods in a free market context, are expected to serve the public interest. While, Walter Lippmann argued in his book Public opinion develops the idea of propaganda that "In order to conduct propaganda, there must be some barrier between the public and the event" (Lippman, 1922). With this division, there is the ability of the media to influence events or present limited information to the general public to change the mind.

\section{Literature review:}

Several studies have been carrying out on the relationship between media and youth, how well the media has performed the duty of defending the public from political propaganda and the perceptions on the media clients. Our literature review discusses here the theories that are important in understanding the relationship between the media and the general public, how media reshaping the perception of educated youth and the views of different authors regarding media unfairness.

Gerbner et. al (1986) argued that The television is a centralized system of storytelling and an integral part of our daily lives. Its drama, commercials, news, and other programs to bring a relatively coherent world of common images and messages in every home; Television cultivates from infancy the same predispositions and 
preferences that used to be acquired by other primary sources. Exceeds all the historical barrier of literacy and mobility, television has become the primary common source of socialization and everyday information (mostly in the form of entertainment) of an otherwise heterogeneous population. The repetitive pattern of messages produced in the television series and fans of mainstream images of a common symbolic environment. Many of those who now live on television have never before been part of a shared national culture. Television provides, perhaps for the first time since the pre-industrial religion, a daily ritual of highly compelling and informative content that forms a strong bond between the cultural elite and the rest of the population.

Fiske (1987), in his book Television Culture, describes as a claw back strategy; news is conveying through a top-to-bottom chain of verbal explanation. Starting from the actually neutral and objective newsroom anchor who usually does not talk his own thoughts, down to newsroom experts, field reporters, and interviewed eyewitnesses and visual figurations of events are made to obey the rules to the elite-dependent idea of the event. The idea of images is particularly self- defeating when it comes to analyses of television news on terror, since their overwhelming power often renders irrelevant the detailed analysis of narrative verbal couching. News reports set in dominant ideologies through the interrelation of spread images and their association with carefully selected headline shots. Negative feelings can also be appeal to by join together events or persons with phenomena or terms that are considered as dangerous, threatening, and extreme.

The semantic coloring of headline shots ideologically characterizes places, event, or people. One of CNN's recurrent headline shots figures Saddam Hussein in a modern black suit, shot from below, drawing a sword and waving it in the air. This formation in CNN newscasts encodes America's dominant ideological perception of Hussein as a dangerous (the low-angle shot imparting menace on Saddam) backward barbarian (he waves a sword) in modern appearance (he wears a Western suit). The low-angled shot also encodes a discussion of coverage. This headline shot 'semantically' dominates and groups other available non-dominant spread images that figure in reports on Iraq. (Lin, 2006).

Herman \& Chomsky (1988) "propaganda model" emphasizes those powerful elites in society, who organize the news resources of and right to use to the media system for their own interest, can project their Industrial motivated political ideology. This, in turn, facilitates the materialization of a "manufactured consent" one that can help advance elite capitalistic economic interests - on weighty issues of Foreign policy such as war. According to (Zaller, 1994a) this type of public consensus can often surface rather quickly in time of a national crisis, triggered by a stream of well-crafted patriotic rhetoric delivered by the power elites (including politicians) and reported by the media, as an unusually large number of citizens may be tuning into news coverage of such crises. This theory Therefore explains why the American government was able to gather the support of the public for its march towards a disastrous Iraq war of 2003 after the 9/11 incident. Therefore, journalists must be prepared to confront powerful voices whose political or economic motives lead them to create their own idiosyncratic standards of impartiality (Gunter, 2009).

The role of the media in shaping public perceptions and opinions about important political and social issues has long been the focus of much theory and discuss. Media play an essential role to reshaping the perception of the educated youth about the social and political issues in the society. (Maeroff, 1998; Spitzer, 1993; Wilson \& Wilson, 2001; Wimmer and Dominick, 1991 as cited in Al-Ameri 2013). This analysis of the influence of the media is complex on in what is called 'Cultivation Theory' (Gerbner et.al 1980). Cultivation Theory hold that the electronic media, such as television, has the power to manipulate our view of the society and it is "mostly dependable for our perceptions of the educated youth day-to-day norms and world reality" (Infante, Rancer \& Womack, 1997, p. 383). Television, in particular, is our major source of information today and has become a part of us and part of our family life. As Gerbner discussed in his theory that television is central arm of society and important part of American family.

\section{Statement of the problem:}

Whether media performing as commercial and global socialization agent role or not

\section{Hypothesis:}

$\circ$ Media is establishing Gujrat's educated youth perception prejudice toward social reality

- Whether TV news contents or program are shaping educated youth views according to set agenda or their own interest and desire

- Does T.V Media only perform the role of business or socializing agent

- The educated youth of Gujrat perceive that T.V media is unfair.

\section{Objective of the study}

$\circ$ To study the role of TV in manipulating the educated youth perception positively or negatively, 
- To investigate the perceptions of Gujrat's educated youth on the unfairness of T.V media.

- To understand the educated youth views regarding media national responsibilities and image building.

- The T.V media really fulfilled its duty of defending the public from political propaganda

- To gauge out does the media affect the pattern of public perception extensively

\section{Methodology of the study}

This research was a quantitative and qualitative text analysis of news stories and transcripts about T.V media (Mass Media) influence. The data was received from two key sources. The first source was analyzing and summarizing journal articles and books that had been published on the subject. The second one was surveying the Gujrat's educated youth. Researcher selected Gujrat area for research, narrow down area into sample and selected the educated youth of Gujrat between 20 to 30 year old ages from University of Gujrat. Sample size for the survey was 100 people lying in the age group of 20 years to 30 years. The data was analyzed by using descriptive statistics with the help of SPSS.

In fact, there are two variables one is independent and other one is dependent. The independent variable is T.V news and current affair programs and dependent variable is educated youth. In current scenario general population as well as the educated youth rely on media for information therefore researcher took educated youth as an under investigate variable in this study. However, independent variable further divided into T.V news bulletin, headlines and current affair programs in which also include infotainment programs (Kamran Khan key saath, Capital Talk, Kal Tak, Awaz Kamran Shahid key Saath, TONIGHT with JASMEEN, Hasseb e Haal etc).

\section{Data Analysis and Interpretation \\ Descriptive Statistics}

In this part of the data analysis section, general description of the data is mentioned by presenting frequency tables of certain required variables.

Table No 1: Use the specified Media For?

\begin{tabular}{|l|l|l|}
\hline Purpose of Media & Frequency & Percent \\
\hline Entertainment & $\mathbf{4 2}$ & $\mathbf{4 2 . 0}$ \\
\hline Updates on news and global events & $\mathbf{3 9}$ & $\mathbf{3 9 . 0}$ \\
\hline Connecting with family and friends & 12 & 12.0 \\
\hline If other; Please specify & 7 & 7.0 \\
\hline Total & $\mathbf{1 0 0}$ & $\mathbf{1 0 0 . 0}$ \\
\hline
\end{tabular}

Table No 1. Show that the majority of respondents (42.0\%) use the TV media for entertainment, $(39.0 \%)$ respondents use the TV media for the updates on news and global events, (12.0\%) respondents use the Specific media for connecting the family and friends

Table No2: Which of the following Channels do you watch?

\begin{tabular}{|l|l|l|l|}
\hline Missing & Channels & Frequency & Percent \\
\hline \multirow{5}{*}{} & Geo News & $\mathbf{6 2}$ & $\mathbf{6 2 . 0}$ \\
\cline { 2 - 5 } & Dunya News & 7 & 7.0 \\
\cline { 2 - 5 } & PTV News & 6 & 6.0 \\
\cline { 2 - 5 } & ARY News & 8 & 8.0 \\
\cline { 2 - 5 } & If other, & $\mathbf{1 3}$ & $\mathbf{1 3 . 0}$ \\
\cline { 2 - 5 } & Total & $\mathbf{9 6}$ & $\mathbf{9 6 . 0}$ \\
\hline \multirow{5}{*}{99} & & 4 & 4.0 \\
\hline Total & & $\mathbf{1 0 0}$ & $\mathbf{1 0 0 . 0}$ \\
\hline
\end{tabular}

Table No 2. Shows that the majority of respondent (62.0\%) watch the Geo News, $8.0 \%$ watches ARY news, $7.0 \%$ watch Dunya News, and $13 \%$ respondents watch other news channels. It also clear reveals that the youth of Gujrat mostly like the Geo news Channels for the sake of information or entertainment

Table No 3: Do you rely on the information being provided to you?

\begin{tabular}{|l|l|l|}
\hline Rely on It for Information & Frequency & Percent \\
\hline Yes & 31 & 31.0 \\
\hline No & 20 & 20.0 \\
\hline Sometimes & $\mathbf{4 9}$ & $\mathbf{4 9 . 0}$ \\
\hline Total & $\mathbf{1 0 0}$ & $\mathbf{1 0 0 . 0}$ \\
\hline
\end{tabular}


Table No 3. It is clearly evident from this that all the three age categories of the youth of Gujrat do consider the information being provided to them as unreliable. The results clearly show that only $31.0 \%$ of the youth relies on the media completely while the remaining $20.0 \%$ do not rely on the media all the time. Majority of the respondents $49 \%$ sometimes rely on the information being provided them. It also clearly reveals the fact that the educated youth of Gujrat still has doubts over the sources and reliability of information being provided to them from different sources.

Table No 4. Which programme you, watch often?

\begin{tabular}{|l|l|l|l|}
\hline Missing & Programme & Frequency & Percent \\
\hline & Kamran Khan key saath & 18 & 18.0 \\
\hline & Capital Talk & 18 & 18.0 \\
\hline & Kal Tak & 4 & 4.0 \\
\hline & Awaz Kamran Shahid key saath & 3 & 3.0 \\
\hline & Off the Record & 5 & 5.0 \\
\hline & TONIGHT with JASMEEN & 1 & 1.0 \\
\hline & Hasseb e Haal & $\mathbf{3 4}$ & $\mathbf{3 4 . 0}$ \\
\hline & If other; please specify & 14 & 14.0 \\
\hline & Total & $\mathbf{9 7}$ & $\mathbf{9 7 . 0}$ \\
\hline $\mathbf{9 9}$ & & $\mathbf{3}$ & $\mathbf{3 . 0}$ \\
\hline Total & & $\mathbf{1 0 0}$ & $\mathbf{1 0 0 . 0}$ \\
\hline
\end{tabular}

Table No 4. Shows that Majority of population likes to watch Hasseb e Hall programme their ratio is $34 \%$, However capital talk and Kamran Khan Key saath watching population ratio is $18 \%$ meanwhile, other programmes ratio is below than these programmes.

Table No 5: Do you discuss the content of this program with peer group and family?

\begin{tabular}{|l|l|l|}
\hline Discuss with Peer Group & Frequency & Percent \\
\hline Seldom & 14 & 14.0 \\
\hline Often & $\mathbf{3 7}$ & $\mathbf{3 7 . 0}$ \\
\hline Always & 13 & 13.0 \\
\hline To some extent & $\mathbf{2 4}$ & $\mathbf{2 4 . 0}$ \\
\hline Not at all & 12 & 12.0 \\
\hline Total & $\mathbf{1 0 0}$ & $\mathbf{1 0 0 . 0}$ \\
\hline
\end{tabular}

Table No 5 . Signify that the $37 \%$ respondents discuss these programmes with their peer group and family frequently, while $24 \%$ discuss rare and those respondents who discuss regularly programme contents ratio is $13 \%$.

Table No 6: Electronic Media provides one-sided information or one way communication regarding some events?

\begin{tabular}{|l|l|l|}
\hline One-sided Information & Frequency & Percent \\
\hline Strongly Disagree & 4 & 4.0 \\
\hline Disagree & 9 & $\mathbf{9 . 0}$ \\
\hline Neutral & 31 & 31.0 \\
\hline Agree & $\mathbf{3 7}$ & 37.0 \\
\hline Strongly Agree & 19 & 19.0 \\
\hline Total & $\mathbf{1 0 0}$ & $\mathbf{1 0 0 . 0}$ \\
\hline
\end{tabular}

$37 \%$ respondents agree that electronic media is one way communication while, $31 \%$ have no respondents on this question and disagree ratio is below than $10 \%$.

\section{Findings and Results:}

Majority of respondents watch the Geo News, few one watches ARY news, while the remaining respondents like other channels. It also clear reveals that the youth of Gujrat mostly like the Geo news Channels for the sake of information or entertainment.

It is clearly evident that the educated youth of Gujrat do consider the information being provided to them as unreliable. The results clearly show that only One third of the population of the youth relies on the media completely while the remaining does not rely on the media all the time. Majority of the 
respondents sometimes rely on the information being provided them. It also clearly reveals the fact that the educated youth of Gujrat still has doubts over the sources and reliability of information being provided to them from different sources.

Masses of respondents like to watch Hasseb e Hall programme However capital talk and Kamran Khan Key saath watching respondents less then this program because they are interested in these programme as well as programme contents. Most of the respondents discuss these programmes with their peer group and family frequently, mostly they pick different point of information from there then they discuss it at different situation and time with others, also they share these information while, some are discuss rare and those respondents but the regularly basis discussion about the program or program contents is in a very low level.

Majority of respondents are agree that electronic media (T.V) provide the one sided information about the events or issues which are happening in the society because they do not treat or handle properly the feed back that come from audience sides an other factor is owner monopoly or any other group, they diminish public feedback and provide the content in which they have interest or want to set the agenda of youth in Pakistan.

\section{Conclusion}

Study results and discussion reveal that electronic media is a powerful tool in Pakistani society in current era. Electronic media outlets provide the information that set of educated youth agenda which owner want and have a desire to set. However these different channels consider as one sided communication in other words bombardment of information if any body do not has interest in particular information but create curiosity to him or her. Finally electronic media also serve as family arm in Pakistani society because mostly people consume for entertainment and education and also rely on it for information. .

\section{References}

[1]. Al-Ameri, Mamdoh Suleiman, "Media and USF Students' Perception of Terrorism" (2013). Graduate School Theses and Dissertations. http://scholarcommons.usf.edu/etd/4429

[2]. Ali, S. Z. (2011). Role of ICTs in Creating Awareness about Rights - A Step towards True Democracy in Pakistan. University of Auckland, New Zealand.

[3]. B. Gunter, M. W. (1993). The Gulf Crisis and Television: The public's response in Britain. Hampton press

[4]. Davenport, L., LaRose, R., \& Straubhaar, J. (2006). Media Now: understanding media, culture and technology. Boston: Wadsworth Publishing Company.

[5]. Davison, W. (1983). The third-person effect in communication. Public Opinion Quarterly, 47, pp. 1-15.

[6]. Fiske, John. 1987. Television Culture. London: Routledge

[7]. Gerbner, George., Gross, Larry., Morgan, Michael., \& Signorielli, Nancy. (1980). The "mainstreaming" of America: Violence profile no. 11.Journal of Communication, 30, 10-29.

[8]. Gerbner, George., Gross, Larry., Morgan, Michael., \& Signorielli, Nancy. (1986). Title: Perspectives on Media Effects. Chapter: 2. Living with Television: The Dynamics of the Cultivation Process. Pages: 17 - 40. Publisher: Hillsdale, NJ: Lawrence Erlbaum Associates:

http://wiki.commres.org/pds/CultivationTheory/LivingWithTelevision TheDynamicsoftheCultivationProcess.pdf

[9]. Gunther, A. C. (1998). The persuasive press inference: Effects of mass media on perceived public opinion. Communications' Research, 25 , pp. 486-504.

[10]. Gunter, B. (2009). The Public and Media Coverage of the War on Iraq. Globalization, Vol. 6, pp. 41-60.

[11]. Herman, E., \& Chomsky, N. (1988). The Political Economy of the Mass Media. New York: Pantheon Books.

[12]. Infante, D., Rancer, A., \& Womack, D. F. (1997). Building Communication Theory, (3rd ed.). Prospect Heights IL: Waveland Press.

[13]. Lin, C. A. (2006). Public Opinion and the Iraq War: The Role of News Perceptions and Core Values. Paper presented at Annual meeting of the International Communication Association. Connecticut: Department of Communication Sciences, University of Connecticut Storrs.

[14]. Lippman, W. (1922). Public opinion. New York: free press paperbacks.

[15]. UNICEF. Children, Youth and Media Around the World: An Overview of Trends \& Issues. 4th World Summit on Media for Children and Adolescents. Rio de Janeiro, Brazil. April 2004. Retrieve: http://www.unicef.org/videoaudio/intermedia revised.pdf

[16]. Zaller, J. (1994a). Elite leadership of mass opinion: New evidence from the Gulf War. Chicago: Public University of Chicago Publisher. 